\title{
LITERASI DIGITAL DAN PENGETAHUAN KOMUNIKASI INFORMASI DIGITAL PADA MASYARAKAT PINGGIRAN KOTA BANJARMASIN (Studi Pada Masyarakat Pinggiran Kota Banjarmasin)
}

\author{
Sarwani $^{1)}$ \\ ${ }^{1)}$ Universitas Lambung Mangkurat Banjarmasin \\ Email : sarwani_komunikasi@ulm.ac.id
}

\begin{abstract}
ABSTRAK
Kota Banjarmasin merupakan pusat Kota Kalimantan Selatan yang dari berbagai kegiatan literasi digital yang pernah dilakukan dalam bentuk pengabdian masyarakat yang dilakukan sejak tahun 2012 khususnya menyusur pada pelajar, guru, dan masyarakat. Karakteristik wilayah atau ciri-ciri wilayah suburban ini merupakan percampuran desa dan kota. Pada penelitian ini persepsi masyarakat pinggiran yang dimaksud adalah pandangan/penilaian dari para orang tua yang tinggal dikawasan pinggiran Kota Banjarmasin tentang pentingnya mengakses internet dan penggunaan media sosial secara sehat dan tepat, dan orang tua berlaku sebagai pengawas atau kontrol bagi anak-anaknya ketika mengakses informasi maupun konten-konten dari internet. Fokus pada penelitian ini adalah pandangan dari orang tua yang bermukim di kawasan pinggiran Kota Banjarmasin yang memiliki anak mulai usia 0 hingga 17 tahun tentang pentingnya literasi digital. Hasil penelitian menunjukkan dengan metode sosialisasi umumnya hanya terbatas pada pemahaman bahwa literasi digital hanyalah berupa kemampuan untuk mengakses informasi melalui internet dan tidak banyak yang mengetahui dan memahami dampak negatif dari mengakses internet tanpa filter diri khususnya bagi anak-anak serta pentingnya pengawasan dari orang tua. Hasil penelitian menunjukkan persepsi masyarakat pinggiran tentang literasi digital dilihat dari indikator kognitif dengan persentase sebesar $51,7 \%$. Pada indikator afeksi dengan persentase sebesar 32,2\%, dan indikator konasi dengan persentase sebesar 16,1\%, sehingga secara keseluruhan persepsi masyarakat pinggiran Kota Banjarmasin terbesar hanya masih dalam tataran pada aspek kognitif awal dengan penilaian kategori sedang. Berangkat dari hal diatas kiranya perlu mengetahui secara lebih lanjut pandangan masyarakat khususnya para orang tua mengenai literasi digital yang ada dibenak masyarakat ditinjau dari aspek kognisi, afeksi dan konasi melalui pengawasan dari Dinas Komunikasi Informasi dan Pemerintah Kota Banjarmasin.
\end{abstract}

Kata Kunci: Literasi Digital; Internet; Masyarakat Pinggiran; Komunikasi Informasi; Kota Banjarmasin.

\section{PENDAHULUAN}

Era tanpa batas tanpa penghalang ruang dan waktu menjadi realitas interaksi dalam perkembangan teknologi informasi saat ini. Umumnya berbagai informasi dengan mudah diakses oleh siapa saja. Menurut Data APJII (2016) Pengguna Internet dilihat dari sisi geografis terbesar berada di pulau Jawa sebanyak 65\% (86.3 juta orang), sisanya tersebar di Sumatera (15.7\%), Sulawesi $(6.3 \%)$ dan Kalimantan (5.8\%). Dua wilayah lainnya yaitu Bali dan Nusa persentasenya di bawah 5\%. Ini memperlihatkan adanya kesenjangan dalam penggunaan Internet. Kesenjangan juga tampak dari segi usia. Dari keseluruhan pengguna Internet, yang dominan adalah kelompok usia 35-44 tahun sebesar 29.2\%, diikuti oleh kelompok usia 25-34 tahun sebanyak 24.4\%. Pada peringkat ketiga, ditempati oleh kelompok usia 10-24 tahun sebanyak $18.4 \%$, diikuti oleh kelompok usia 45-54 tahun sebanyak $18 \%$. Kelompok usia di atas 55 tahun jumlahnya sebanyak $10 \%$. Kelompok usia yang paling produktif, yaitu 25-44 tahun jumlahnya mencapai $53.6 \%$ atau sebanyak 71 juta orang, menjadi pengguna Internet yang paling dominan.
Selanjutnya dari segi profesi, pengguna Internet didominasi oleh kelompok pekerja/wiraswasta sebanyak $62 \%$ atau 82.2 juta orang. Data juga menunjukkan bahwa pada peringkat kedua, ibu rumah tangga menjadi pengguna internet terbanyak dengan jumlah 22 juta orang atau 16.6\%. Pada peringkat ketiga, terdapat kelompok mahasiswa dengan jumlah 10.3 juta (7.8\%). Kelompok pelajar berjumlah 8.3 juta orang $(6.3 \%)$. Berdasarkan data tersebut Kalimantan Selatan khususnya Kota Banjarmasin yang merupakan bagian dari Kalimantan merupakan pengguna dengan kategori tidak sebesar masyarakat di Pulau Jawa.

Kota Banjarmasin merupakan pusat Kota Kalimantan Selatan yang dari berbagai kegiatan literasi digital yang pernah dilakukan oleh peneliti dalam bentuk pengabdian masyarakat yang dilakukan sejak tahun 2012 khususnya menyusur pada pelajar, guru, dan masyarakat dengan metode sosialisasi umumnya hanya terbatas pada pemahaman bahwa literasi digital hanyalah berupa kemampuan untuk mengakses informasi melalui internet dan tidak banyak yang mengetahui dan memahami dampak negatif dari mengakses internet 
tanpa filter diri khususnya bagi anak-anak serta pentingnya pengawasan dari orang tua. Berangkat dari hal diatas kiranya perlu mengetahui secara lebih lanjut pandangan masyarakat khususnya para orang tua mengenai literasi digital yang ada dibenak masyarakat ditinjau dari aspek kognisi, afeksi dan konasi dimana fokus pada penelitian ini adalah pandangan dari orang tua yang bermukim di kawasan pinggiran Kota Banjarmasin yang memiliki anak 0 -17 tahun tentang pentingnya literasi digital. Mengingat kawasan yang banyak tidak tersentuh dengan pengetahuan literasi digital yaitu kawasan masyarakat pinggiran kota, maka dalam penelitian ini mengarah kepada kawasan pinggiran perkotaan, dimana pinggiran perkotaan atau suburban adalah suatu daerah pemukiman atau perumahan yang terletak dipinggiran kota, tetapi tidak jauh dari pusat kota. Kemunculan suburban sendiri lebih didasari karena adanya pemekaran kota dimana bertambahnya berbagai akses jalanjalan baru yang menyebabkan terjadinya perluasan lahan. Masyarakat pinggiran perkotaan atau masyarakat suburban adalah masyarakat yang mempunyai rumah dan tinggal di pinggiran kota. Suburban area merupakan area dimana para commuter tinggal. Karakteristik wilayah atau ciriciri wilayah suburban ini merupakan percampuran desa dan kota. Beberapa daerah akan menunjukkan bentuk kota, tetapi disisi lain menunjukkan ciri khas pedesaan, dimana memang pada awalnya merupakan wilayah pedesaan yang mengalami proses transisi menjadi daerah perkotaan. Inilah disebut bahwa daerah pinggiran kota akan mengalami proses transformasi sosial ekonomi sebagai dampak lebih lanjut dari proses transformasi spasial.

Pada penelitian ini persepsi masyarakat pinggiran yang dimaksud adalah pandangan/penilaian dari para orang tua yang tinggal dikawasan pinggiran Kota Banjarmasin tentang pentingnya mengakses internet dan penggunaan media sosial secara sehat dan tepat, dan orang tua berlaku sebagai pengawas atau kontrol bagi anak-anaknya ketika mengakses informasi maupun konten-konten dari internet termasuk juga orang tua mengontrol dirinya dalam menggunakan media daring, sehingga dalam penelitian ini dirumuskan seberapa besar nilai persepsi yang dimilki oleh para orang tua tentang pentingnya literasi digital berdasarkan aspek persepsi yaitu kognisi, afeksi dan konasi, sehingga akan diketahui persepsi orang tua tentang literasi digital ini berada pada aspek yang mana yang ditunjukkan.

\section{Persepsi Masyarakat}

Menurut Rahmat (2004:51) persepsi adalah pengalaman tentang objek, peristiwa atau hubungan-hubungan yang diperoleh dengan menyimpulkan informasi dan menafsirkan pesan. Persepsi memberikan makna pada stimulus inderawi, jadi hubungan sensasi dengan persepsi sudah jelas, sensasi adalah bagian dari persepsi. Ada beberapa sub proses di dalam persepsi, dan yang dapat dipergunakan sebagai bukti bahwa sifat persepsi itu merupakan hal yang kompleks dan interaktif, sub proses pertama yang dianggap penting ialah stimulus atau situasi yang hadir. Mula-mula terjadinya persepsi diawali ketika seseorang dihadapkan dengan situasi atau stimulus, situasi tersebut bisa berupa penginderaan dekat dan langsung atau berupa bentuk lingkungan sosio kultur dan fisik yang menyeluruh. Setelah mendapat stimulus, pada tahap selanjutnya terjadi seleksi yang berinteraksi dengan 'interpretation', begitu juga berinteraksi dengan 'closure'. Proses interpretasi ini tergantung pada cara pendalaman (learning) seseorang, motivasi dan kepribadian seseorang interpretasi terhadap sesuatu informasi yang sama akan berbeda untuk setiap orangnya sehingga tahap ketiga ini menjadi penting dalam memahami persepsi. Selanjutnya proses umpan balik (feed back) dari peristiwa maupun objek.

Menurut Robbins (2001:88) persepsi adalah suatu proses dimana individu mengorganisasikan dan menafsirkan kesan indera mereka agar memberi makna kepada lingkungan mereka. Perbedaan dalam mempersepsikan suatu benda yang sama secara berbeda dipengaruhi oleh pelaku persepsi yaitu penafsiran yang sangat dipengaruhi oleh karakteristik pribadi pelaku seperti sikap, minat dan motif.

Menurut Rahmat (2004:42) persepsi dipengaruhi oleh beberapa faktor dan faktor-faktor personal yang mempengaruhi persepsi tersebut adalah (1) Pengalaman yaitu apa yang dialami oleh perseptor. Pengalaman ini biasa diperoleh melalui berbagai jalan, diantaranya melalui proses belajar, selain melalui proses rangkaian peristiwa yang pernah dialami seseorang, baik peristiwa buruk maupun baik; (2) Motivasi yaitu seseorang hanya akan mendengar apa yang ia mau dengar, seseorang mau melakukan sesuatu jika itu berguna bagi dirinya, oleh karena setiap orang mempunyai kepentingan dan keperluan yang berbeda antara yang satu dengan yang lainnya; dan (3) Pengetahuan seseorang diperlukan untuk suatu kecerdasan persepsi. Persepsi ini bisa diukur melalui tingkat pendidikan tinggi dengan sendirinya tingkat pengetahuannya pun menjadi luas. Berdasarkan beberapa point penting diatas, 
maka batasan pengertian dalam kajian ini adalah suatu proses penafsiran seseorang terhadap suatu obyek tertentu melalui panca indera, yang dilakukan dalam batasan-batasan kesadaran tertentu dan berdasarkan pada suatu pengalaman yang pernah dirasakan.

\section{Literasi Digital}

Literasi yang dalam bahasa Inggrisnya literacy berasal dari bahasa Latin littera (huruf) yang pengertiannya melibatkan penguasaan sistemsistem tulisan dan konvensi-konvensi yang menyertainya. Namun demikian, literasi utamanya berhubungan dengan bahasa dan bagaimana bahasa itu digunakan. Adapun sistem bahasa tulis itu sifatnya sekunder. Manakala berbicara mengenai bahasa, tentunya tidak lepas dari pembicaraan mengenai budaya karena bahasa itu sendiri merupakan bagian dari budaya. Sehingga, pendefinisian istilah literasi tentunya harus mencakup unsur yang melingkupi bahasa itu sendiri, yakni situasi sosial budayanya.

Literasi memerlukan kemampuan yang kompleks. Adapun pengetahuan tentang genre adalah pengetahuan tentang jenis-jenis teks yang berlaku/ digunakan dalam komunitas wacana misalnya, teks naratif, eksposisi, deskripsi dan lainlain. Terdapat tujuh unsur yang menjadi tujuh prinsip dalam literasi melibatkan beberapa hal yaitu interpretasi, kolaborasi, konvensi, pengetahuan kultural, pemecahan masalah, refleksi, dan penggunaan bahasa.

Literasi media di Indonesia lebih dikenal dengan istilah melek media. Potter (2008) mengatakan bahwa literasi media adalah sebuah perspekif yang digunakan secara aktif ketika individu mengakses media dengan tujuan untuk memaknai pesan yang disampaikan oleh media. Rubin kemudian menyatakan defenisi literasi media sebagai berikut : Media literacy, then, is about understanding the sources and technologies of communication, the codes that are used, the messages that are produced, and the selection, interpretation, and impact of those messages.

Literasi media adalah pemahaman terhadap sumber-sumber dan teknologi komunikasi, simbolsimbol yang digunakan, dan proses seleksi, interpretasi, dan dampak dari pesan-pesan tersebut. Kemudian The National Communication Association dalam Potter (2010:677), sebuah organisasi sarjana professional yang didirikan oleh sejumlah besar akademisi universitas menyatakan bahwa literasi media adalah :

\begin{abstract}
Being a critical and reflective consumer of communication requires anunderstanding of how words, images, graphics, and sounds work together in ways that are both subtle and profound. Mass media such as radio, television, and film and electronic media such as the telephone, the internet, and computer conferencing influence the ways meanings are created and shared in contemporary society. So great is this impact that in choosing how to send a message and evaluate its effect, communicators need to be aware of the the distinctive characteristic of each medium.
\end{abstract}

Dalam perkembangan literasi media yang dimulai dari literasi klasik (membaca, menulis, memahami) yang mendominasi abad dan menghubungkan kepada proses membaca dan menulis, serta di sekolah-sekolah dasar telah digunakan sebagai aturan dasar. Literasi audiovisual, yang menghubungkan kepada media elektronik sepertifilm dan televisi, fokus pada gambar dan rangkaian gambar. Ini merupakanpermulaan dari pendidikan berbeda yang digagas dengan segera tetapi tidak didukung penuh oleh kebijakan yang nyata. Perkembangan selanjutnya adalah Informasi atau digital literasi yang berasal dari komputer dan media digital yang telah membuat pentingnya belajar keterampilan baru. Ini merupakan konsep terbaru dan sering digunakan untuk mengacu pada keterampilan teknik yang diperlukan untuk peralatan digital modern, dan literasi media yang dibutuhkan sebagai hasil dari konvergensi media - yang menggabungkan media elektronik (komunikasi massa) dan media digital (komunikasi multimedia) yang terjadi dalam berbagai perkembangan masyarakat informasi. Literasi Media ini meliputi beragam bentuk literasi: membaca, menulis, audiovisual, digital dan keterampilan baru yang diperlukan dalam sebuah iklim konvergensi media.

Literasi digital yang juga dikenal sebagai literasi komputer merupakan salah satu komponen dalam kemahiran litrasi media yang merupakan kemahiran penggunaan komputer, internet, telepon and peralatan digital yang lain. Literasi digital merujuk pada adanya upaya mengenal, mencari, memahami dan menganalisis serta menggunakan teknologi digital. Literasi digital adalah 
ketertarikan, sikap dan kemampuan individu dalam menggunakan teknologi digital dan alat komunikasi untuk mengakses, mengelola, mengintegrasikan, menganalisis, dan mengevaluasi informasi, membangun pengetahuan baru, membuat dan berkomunikasi dengan orang lain agar daoat berpartisipasi secara efektif didalam masyarakat. Media digital termasuk salah satu gadget dalam media baru, definisi media baru Dennis McQuail (2000) dalam (Ibrahim dan Akhmad, 2014) terdapat empat kategori utama, yaitu :

1. Media komunikasi interpersonal seperti $e$ mail.

2. Media permainan interaktif seperti game.

3. Media pencarian informasi seperti mesin pencarian di internet,

4. Media partisipatoris seperti ruang chat di internet.

Dalam penelitian ini yang dimaksud dengan literasi media digital adalah keahlian atau kemampuan seseorang memanfaatkan komputer, internet, telepon dan peralatan digital yang lain sebagai alat penunjang komunikasi secara benar dan optimal. Pertumbuhan media sosial seperti, FB, Twitter, dan lainnya mulai mendominasi budaya masyarakat. Oleh sebab itu bila seseorang memiliki literasi media ia akan dapat mengembangkan kompetensi yang dimilikinya.

\section{METODE PENELITIAN}

Penelitian ini menggunakan pendekatan kuantitatif, karena bertujuan untuk menguji atau mengetahui persepsi masyarakat tentang literasi digital . Penelitian Kuantitatif adalah penelitian yang ilmiah yang sistematis terhadap bagianbagain dan fenomena serta hubunganhubungannya. Tujuan penelitian kuantitatif adalah mengembangkan dan menggunakan model-model matematis, teori-teori dan hipotesis yang dikaitkan dengan fenomena alam. Penelitian kuantitatif banyak digunakan untuk menguji suatu teori, untuk menyajikan suatu fakta atau mendeskripsikan statistik, untuk menunjukkan hubungan antarvariabel, dan ada pula yang bersifat mengembangkan konsep, mengembangkan pemahaman atau mendeskripsikan banyak hal, baik itu dalam ilmu-ilmu alam maupun ilmu-ilmu sosial. Dalam penelitian ini penulis menggunakan metode survei yaitu metode penelitian dengan menggunakan kuisioner sebagai instrument pengumpulan datanya. Tipe penelitian yang digunakan dalam penelitian ini adalah tipe deskriptif.

Teknik pengumpulan data primer dalam penelitian ini adalah dengan menggunakan kuesioner sebagai alat utama untuk memperoleh data dengan mengajukan 8 item pernyataan dengan teknik penentuan skor menggunakan skala likert. Hasil uji validitas tiap instrument dalam penelitian ini dengan menggunakan metode person product momen diperoleh $r$ antara 0,498 sampai dengan 0,718 dan jika dibandingkan dengan r-tabel 0,324 dapat dinyatakan koefisien korelasi pernyataan dinyatakan valid dan koefisien realibiltas dengan menggunakan alpha cronbach dengan nilai standar 0,6 dan hasil uji realibiltas menunjukkan angka 0,745 sehingga seluruh item pernyataan adalah realibel.

\section{HASIL PENELITIAN DAN PEMBAHASAN}

Data dalam penelitian ini diperoleh berdasarkan kuesioner yang disebar kepada masyarakat yang tinggal diwilayah pinggiran perkotaan Kota Banjarmasin meliputi wilayah Kecamatan Banjarmasin Selatan, Banjarmasin Timur, Banjarmasin Barat, dan Banjarmasin Utara yang memiliki karakteristik sesuai dengan yang telah ditentukan oleh peneliti.

\section{Karakateristik Responden}

Karakteristik responden berdasarkan criteria yang ditetapkan dalam penelitian ini adalah berusia 15-59 tahun, tahu tentang internet, pernah mengakses internet dan memiliki anak berusia 0-17 tahun dengan jumlah sampel/responden sebesar 348, dimana untuk karakteristik responden diltinjau dari jenis kelamin, tingkat usia, tingkat pendidikan dan jenis pekerjaan.

Responden pada penelitian ini lebih banyak berjenis kelamin perempuan sebanyak 221 orang atau 64\% dan Laki-Laki 127 orang atau 36\%. Hal ini juga menunjukkan bahwa tahu ada internet, pengguna internet dan mengakses internet untuk berbagai keperluan didominasi juga oleh kaum perempuan dan berstatus ibu rumah tangga.

Usia responden terbesar berada pada penelitian ini adalah pada usia 20-24 tahun sebanyak 128 orang atau sekitar $36.78 \%$ dan diikuti oleh usia 15-19 tahun $19.82 \%$, dimana mencapai $56,6 \%$ telah memiliki anak pada usia muda dan sejalan dengan data pada masyarakat yang tinggal dikawasan pinggiran Kota 
Banjarmasin umumnya banyak yang menikah pada usia muda.

Tingkat pendidikan umumnya dapat pula menentukan tentang cara berpikir seseorang tentang berbagai hal. Dan dalam penelitian ini karakteristik responden juga dilihat berdasarkan tingkat pendidikan responden terbesar berada pada tingkat SMA sebanyak 132 orang atau 37,93\%, akan tetapi dengan kategori tidak menyelesaikan pendidikan dasar yaitu tidak sekolah/tidak tamat SD, SD dan SMP jauh lebih besar yaitu sebanyak 208 orang atau 59,77\%\%, sehingga berdasarkan data ini sejalan dengan hasil observasi awal peneliti bahwa masyarakat yang tinggal di pinggiran Kota Banjarmasin memilki kecenderungan tingkat pendidikan yang rendah.

Berdasarkan data responden, umumnya responden dalam penelitian ini adalah ibu rumah tangga sebanyak 167 orang atau 47,98\% dan dikuti oleh pekerjaan jenis lainnya. Pekerjaan jenis lainnya ini seperti berdagang, buruh tani, pembantu rumah tangga, buruh cuci, dan lainnya.

\section{Uji Deskriptif}

Uji deskriptif adalah statistika yang digunakan untuk menganalisis data dengan cara mendeskripsikan atau menggambarkan data yang telah terkumpul sebagaimana adanya tanpa bermaksud membuat kesimpulan yang berlaku secara umum atau dapat digenaralisasikan. masingmasing aspek persepsi sebagai berikut :

Berdasarkan data yang dihimpun diketahui bahwa para orang tua dengan skor pernyataan 1445 adalah sebanyak 180 orang atau $51,7 \%$ berada pada aspek kognisi, dimana aspek ini hanya pada tataran responden tahu bahwa internet itu ada dengan berbagai varians seperti facebook, twitter, BBM, dan lain-lain dan juga mengetahui bahwa internet hanya untuk mencari informasi saja, dalam artian persepsi tentang literasi digital pada aspek kognisi ini hanya pada tahapan awal bahwa intenet itu sudah ada dan dapat diakses oleh siapa saja.

Berdasarkan data yang dihimpun diketahui bahwa para orang tua dengan skor pernyataan 916 adalah sebanyak 112 orang atau $32,2 \%$ berada pada aspek afeksi, dimana aspek ini responden sudah dapat menerima atau merasakan atau pula sangat memerlukan bahwa internet itu ada dengan berbagai varians seperti facebook, twitter, BBM, dan lain-lain. Dalam hal ini aspek afeksi tidak hanya untuk kegiatan berkomunikasi dan mengakses internet untuk mencari informasi saja, akan tetapi pada aspek ini intenet itu dianggap mampu memberikan jawaban atas kebutuhan lain seperti dengan internet dapat menjalin silahturahmi, memiliki banyak teman dan menerima intenet telah menjadi bagian yang tak terpisahkan dari kebutuhan manusia zaman sekarang.

Berdasarkan data yang dihimpun diketahui bahwa para orang tua dengan skor pernyataan 439 adalah sebanyak 56 orang atau 32,2\% berada pada aspek konasi, dimana aspek ini responden sudah dapat melaksanakan atau menerapkan internet itu dengan berbagai varians seperti facebook, twitter, BBM, dan lain-lain sebagai bagian penting dalam aktivitasnya. Dalam hal ini aspek konasi tidak hanya untuk kegiatan berkomunikasi, mengakses internet untuk mencari informasi saja, atau untuk menjalin silahturahmi akan tetapi penggunaan internetpun sudah ditunjukkan untuk menunjang berbagai kegiatan yang dilakukan bahkan dapat membedakan konten dan menerapkan konten positif dalam kehidupannya.

Dari data yang dihimpun ini diketahui bahwa setelah perhitungan seluruh aspek persepsi, maka secara keseluruhan aspek persepsi orang tua pada masyarakat pinggiran Kota Banjarmasin secara deskriptif berada pada nilai rerata sebesar 18,96. Nilai rerata ini menunjukkan bahwa komponen aspek kognisi, afeksi dan konasi yang melingkupi persepsi berada rerata nilai yang standart dalam arti tidak tinggi maupunrendah.

Tabel 1. Kategori Skor Persepsi Orang Tua tentang Literasi Digital

\begin{tabular}{|l|c|c|}
\hline $\begin{array}{l}\text { Interval } \\
\text { Kecenderungan }\end{array}$ & Skor & $\begin{array}{c}\text { Kategor } \\
\text { isasi }\end{array}$ \\
\hline Nilai $\geq$ Mean + & $18,96 \geq$ & Tinggi \\
Standar Deviasi & 22,42 & \\
\hline Mean - Standar & $15,50 \leq$ & Sedang \\
Deviasi $\leq$ Nilai $<$ & 22,42 & \\
Mean + Standar & & \\
Deviasi & & \\
\hline Nilai < Mean - & $18,96<$ & Rendah \\
Standar Deviasi & 15,50 & \\
\hline
\end{tabular}

Sumber : Data diolah peneliti, 2021

Berdasarkan data diatas diketahui bahwa persepsi orang tua tentang literasi digital berkaitan dengan penggunaan internet secara spesifik seperti media sosial facebook, twitter, whatsapp, line, dan lain-lain telah masuk dalam tahapan persepsi pada masyarakat dengan kategori aspek perpsei yang berbeda-beda, tertinggi apsek persepsi adalah 
kategori kognisi dan berada pada kategori sedang, dalam artian kognisi yang dimaksud juga belum menyentuh arti dari kognisi yang sebenarnya karena hanya pada tatatan mengetahui internet sebagai media informasi.

Dari hasil penelitian ini sejalan dengan pendapat Rubin yang dikutip oleh Baran (2004:51) menawarkan tiga definisi mengenai literasi media digital dimana diperoleh pemahaman tentang literasi digital pada masyarakat yang dikutip dari berbagai sumber yang berbeda, yaitu :

1. Definisi pertama menyebutkan bahwa literasi media adalah kemampuan untuk mengakses, menganalisis, mengevaluasi dan mengkomunikasikan pesan.

2. Definisi kedua bahwa literasi media adalah pengetahuan tentang bagaimana fungsi media dalam masyarakat.

3. Definisi ketiga dari peneliti komunikasi massa, Justin Lewis dan Shut Jally, menyebutkan bahwa literasi media adalah pemahaman akan batasanbatasan budaya, ekonomi, politik dan teknologi terhadap kreasi, produksi dan transmisi pesan.

Dalam penelitian memiliki kecenderungan literasi digital pada definisi sesuai dengan aspek persepsi yang diperoleh yaitu aspek kognisi dalam tataran hanya kemampuan untuk mengakses pesan/informasi melalui media. Selanjutnya dari hasil penelitian ini juga diketahui bahwa dalam diri manusia ketika mempersepsi sesuatu itu sangat dipengaruhi oleh berbagai faktor yang ada pada diri individu dan ini sejalan dengan pendapat Rahmat (2004:42) adapun faktor-faktor yang mempengaruhi pengembangan persepsi seseorang, antara lain : (1) Psikologi yaitu persepsi seseorang mengenai segala sesuatu dialami dunia ini sangat dipengaruhi oleh keadaan psikologi, yang indah, tentram, akan tetapi akan dirasakan sebagai bayang-bayang kelabu bagi seseorang yang buta warna; (2) Keluarga memiliki pengaruh yang paling besar terhadap anak-anak. Orang tua yang telah mengembangkan suatu cara yang khusus di dalam memahami dan melihat kenyataan di dunia ini, banyak sikap dan persepsi-persepsi mereka yang diturunkan kepada anak-anaknya; dan (3) Kebudayaan lingkungan masyarakat tertentu juga merupakan salah satu faktor yang kuat di dalam mempengaruhi sikap, nilai, dan cara seseorang memandang dan memahami keadaan dunia ini. Oleh karena itu dengan adanya persepsi akan mempengaruhi perilaku dan membentuk sikap. Dan bagi masyarakat suburban khususnya di Kota Banjarmasin kegiatan literasi digital hanyalah berfungsi sebagai kegiatan yang diketahui dapat memberikan informasi yang dibutuhkan oleh masyarakat.

\section{PENUTUP}

Berdasarkan hasil penelitian diatas dapat ditarik simpulan dalam penelitian ini adalah persepi masyarakat pinggiran khususnya orang tua tentang literasi digital berdasarkan aspek kognisi berada pada rerata 180,6 atau dengan persentase $51,7 \%$. Aspek afeksi berada pada rerata 114,5 atau dengan persentase sebesar $32,2 \%$ dan aspek konasi berada pada rerata 54,9 atau dengan persentase $16,1 \%$. Dengan perhitungan secara keseluruhan diperoleh nilai persepsi orang tua tentang literasi digital adalah berada pada nilai rerata 18,96 dengan persentase $51,7 \%$ dengan kategori sedang dan hanya berada pada aspek kognisi dalam tataran awal yang berarti belum sampai pada penerapan. Memperhatikan hal tersebut, maka sangat dibutuhkan literasi digital secara meluas/gerakan internet sehat kepada masyarakat dan bersifat terus menerus terutama bagi masyarakat yang berpendidikan rendah dan target group juga kepada ibu-ibu rumah tangga sehingga dapat menjadi filter awal untuk mengawasi setiap konten internet yang diakses oleh anak-anaknya.

\section{REFERENCE}

Effendy, Onong Uchjana . (2005) Ilmu

Komunikasi Teori dan Praktek. Bandung. PT Remaja Rosdakarya.

Ibrahim., Idi Subandy, Akhmad (2014) Komunikasi dan Komodifikasi : Mengkaji Media dan Budaya dalam Dinamika Globalisasi. Jakarta : Yayasan Pustaka Obor Indonesia.

Ihalau.J, Prasetijo, R (2005) Perilaku

Konsumen, Yogyakarta :Andi Offset.

Mulyana, Deddy.( 2000 ) Ilmu Komunikasi : Suatu Pengantar. Bandung : PT Remaja Rosdakarya

Rakhmat, Jalaluddin. (2004) Psikologi Komunikasi. Jakarta: PT. Remaja Rosdaskarya

Robbins, Stephen. (2001). Perilaku Organisasi. Jakarta : PT. Indeks Gramedi

Sugiyono. 2009. Metode Penelitian Administrasi.Bandung: Alfabeta. Tangkilisan, Nogi Hessel. (2005) . Manajemen Publik. PT. Gramedia Widiasarana 
MUTAKALLIMIN; Jurnal Ilmu Komunikasi

Vol 4 No 2 November 2021

Thoha, Miftah. (2007). Perilaku Organisasi :

Konsep Dasar dan Aplikasinya. Jakarta :

CV Rajawali.

Walgito, Bimo. (2003). Psikologi Sosial : Suatu Pengantar. Yogyakarta: CV.Andi Offset 